\title{
Endoglucanase and Xylanase Production by Chryseobacterium Species Isolated from Decaying Biomass
}

\author{
Asisipho Nkohla ${ }^{1,2}$, Kunle Okaiyeto ${ }^{1,2}$, Uchechukwu U. Nwodo, ${ }^{1,}$, \\ Leonard V. Mabinya ${ }^{1,2}$, Anthony I. Okoh ${ }^{1,2}$ \\ 'SAMRC Microbial Water Quality Monitoring Centre, University of Fort Hare, Alice 5700, South Africa \\ ${ }^{2}$ Applied and Environmental Microbiology Research Group (AEMREG), Department of Biochemistry \\ and Microbiology, University of Fort Hare, Alice 5700, South Africa
}

Received: 7 November 2016

Accepted: 13 February 2017

\begin{abstract}
Lignocellulosic materials are potential sources of isolating bacteria that can be used to produce important value-added products such as cellulase (endoglucanase) and xylanase in industry. Based on the above-mentioned premise, this study aimed to assess endoglucanase and xylanase-degrading potentials of a bacterial isolate from decaying sawdust samples collected from a wood factory at Melani village, Nkonkobe Municipality of Eastern Cape Province, South Africa. The bacteria showed high activity for endoglucanase and xylanase when grown on carboxymethyl cellulose (CMC) and birch wood xylan as sole carbon sources, respectively. The bacterial isolate was identified through $16 \mathrm{~S}$ rDNA sequencing and the gene sequence was found to have $98 \%$ similarity with that of Chryseobacterium taichungense. The sequence was deposited in the GenBank as Chrysobacterium taichungense SAMRC-UFH2 with accession number KU171370. Optimum culture conditions for endoglucanase and xylanase production included: $\mathrm{pH}$ 6, incubation temperature $\left(25^{\circ} \mathrm{C}\right)$, and agitation rates of $50 \mathrm{rpm}$ and $150 \mathrm{rpm}$ for endoglucanase and xylanase, respectively. The high enzyme activities exhibited by this bacterial strain portend it as a potentially relevant candidate as a producer for value-added products of biotechnological importance.
\end{abstract}

Keywords: lignocellulosic materials, Chrysobacterium sp. SAMRC-UFH2, submerged fermentation, endoglucanase, xylanase

\section{Introduction}

The existence of pollution problems associated with agro-industrial wastes, scarcity of places for its

*e-mail: UNwodo@ufh.ac.za

disposal, costlier treatment options, and increased need to save valuable resources have forced the utilization and bioconversion of waste (lignocellulosic materials) into high-value industrially useful products. The huge amount of residual plant biomass considered as "waste" can be a potential source of isolating microorganisms, which can be used to produce various value-added products like biofuels, animal feeds, chemicals, and enzymes [1]. The demand for industrial enzymes, particularly of microbial 
origin, is ever increasing due to their application in a wide variety of processes [2].

Many bacteria and fungi are capable of utilizing cellulose as their carbon source by synthesizing cellulases as inducible enzymes that are responsible for the degra-dation of cellulose into simple sugars composed predominantly of glucose [3]. The comprehensive hydrolysis of cellulosic matter requires a combined action of a variety of cellulases (1,4- $\beta$-D-glucanglucanohydrolase, EC 3.2.1.4) that are multienzyme complexes, comprising three main components that have been shown to act synergistically in the hydrolysis of cellulose to glucose units [4]: endo- $\beta$-glucanase (EC 3.2.1.4), exo- $\beta$-glucanase (EC 3.2.1.91), and $\beta$-glucosidase (EC 3.2.1.21).

Xylan is known to be the second richest natural polysaccharide of plant biomass and is considered one of the most significant polysaccharides for industrial applications [5-6]. Its primary chain is made up of $\beta$-xylopyranose residues and the complete enzymatic hydrolysis of this chain needs a series of enzymes with endo-1,4- $\beta$-D-xylanase (EC 3.2.1.8), the most fundamental in the depolymerisation of xylan [Polizeli et al., 2005]. The diversity in chemical arrangements of xylans resulting from the cell walls of different plant materials has led to many different xylanases that have dissimilar physicochemical attributes, structures, and hydrolytic activities [7].

Microorganisms from different environments are prospective sources of cellulase as well as xylanase for biotechnological use. Such environments may have extremes of $\mathrm{pH}$, temperature, and even salt content; hence these organisms produce enzymes that have been developed to operate optimally under some of these harsh conditions [8].

The genus Chryseobacterium is ubiquitous in nature. The taxonomy of these yellow pigmented, gram-negative rods is incorporated in the taxonomy of the Flavobacterium genus. Flavobacterial microbes have been documented as the causatives of food spoilage for many food products such as poultry, meat, fish, milk, and other dairy foods [9]. Flavobacterium genus is known to be the source of the bitter and fruity flavours in milk, and the slime production and discolouration in cheese [10]. Currently, many Flavobacterium species that were once known to cause food spoilage have been reclassified as Chryseobacterium genus. Furthermore, there are quite a number of reports on the pathogenicity of several Chryseobacterium species to animals and humans [11]. Chryseobacterium indologenes and Chryseobacterium gleum have the ability to cause nosocomial infections in humans, and this commonly happens in infants and patients with compromised immune systems with underlying diseases [11].

To the best of our knowledge, nowhere in the literature has Chrysobacterium taichungense been implicated in cellulose or xylan degradation. Hence, this present study describes cellulose and xylan-degrading potentials of a Chrysobacterium sp. isolated from decaying sawdust in the Eastern Cape Province of South Africa. The ability of the bacteria to produce endoglucanase and xylanase was assessed and the culture conditions for their optimum production were further investigated.

\section{Materials and Methods}

The decaying biomass (sawdust) samples were collected from a wood factory at Melani village, Nkonkobe Municipality of Eastern Cape Province, South Africa. The samples were aseptically collected into sterile plastic bags and transported on ice to the laboratory of the Applied and Environmental Microbiology Research Group (AEMREG) for further analyses.

The growth media used in the experiments included R2A agar supplemented with Nystatin $(50 \mathrm{mg} / \mathrm{l})$ to retard fungal growth and contained yeast extract $(0.5 \mathrm{~g} / \mathrm{l})$, protease peptone $(0.5 \mathrm{~g} / \mathrm{l})$, casamino acids $(0.5 \mathrm{~g} / \mathrm{l})$, glucose $(0.5 \mathrm{~g} / \mathrm{l})$, soluble starch $(0.5 \mathrm{~g} / \mathrm{l})$, dipotassium phosphate $(0.3 \mathrm{~g} / \mathrm{l}), \mathrm{MgSO}_{4} .7 \mathrm{H}_{2} \mathrm{O}(0.5 \mathrm{~g} / \mathrm{l})$, sodium pyruvate $(0.3 \mathrm{~g} / \mathrm{l})$, and agar $(15.0 \mathrm{~g} / \mathrm{l})$. Luria Bertani (LB) broth contained peptone $(10.0 \mathrm{~g} / \mathrm{l})$, yeast extract $(5.0 \mathrm{~g} / \mathrm{l})$, and $\mathrm{NaCl}$ $(5.0 \mathrm{~g} / 1)$. Basal agar medium contained carboxymethyl cellulose (CMC) $(5.0 \mathrm{~g}), \mathrm{NaNO}_{3}(1.0 \mathrm{~g}), \mathrm{K}_{2} \mathrm{HPO}_{4}(1.0 \mathrm{~g})$, $\mathrm{KCl}(1.0 \mathrm{~g}), \mathrm{MgSO}_{4} .7 \mathrm{H}_{2} \mathrm{O}(0.5 \mathrm{~g})$, yeast extract $(0.5 \mathrm{~g})$, and agar $(15.0 \mathrm{~g})$ in 1 litre of distilled water. For basal medium containing xylan agar, CMC $(5.0 \mathrm{~g})$ was replaced with birchwood xylan (5 g) [12].

Isolation of the bacteria was carried out in accordance with the modified method of Jeffrey [13]. Briefly, $1 \mathrm{~g}$ of the sawdust was mixed with $100 \mathrm{ml}$ of sterile distilled water $\left(\mathrm{sdH}_{2} \mathrm{O}\right)$. The sawdust suspension was then stirred vigorously at room temperature $\left(28^{\circ} \mathrm{C}\right)$ on a shaker at $200 \mathrm{rpm}$ for $1 \mathrm{~h}$. A series of dilutions of the suspension from $10^{0}$ to $10^{-6}$ were prepared in sterile phosphate buffer saline (PBS), and $100 \mu \mathrm{l}$ of the diluted suspensions was spread onto the surface of the growth media. All the plates were then incubated at $28^{\circ} \mathrm{C}$ for about a week. At the end of the incubation period, typical bacterial colonies were selected based on their morphology, size, and colour, and streaked again onto fresh R2A medium plates for purity and incubated further at $28^{\circ} \mathrm{C}$ for one week. After purification, the colonies were compared visually to separate those with similar colonial characteristics, and discrete colonies were sub-cultured again and glycerol stock cultures were prepared from the pure colonies and stored at $-80^{\circ} \mathrm{C}$ for future use.

Test tubes containing $10 \mathrm{ml}$ of sterile nutrient broth (NB) were inoculated with a loop full of the purified isolates and incubated with shaking at $150-200 \mathrm{rpm}$ at $28^{\circ} \mathrm{C}$ for $48 \mathrm{~h}$. After incubation, $1 \mathrm{ml}$ of the culture suspension was transferred to sterile Eppendorf tubes and centrifuged at high speed for 5-10 min to sediment the cells. The supernatant was carefully decanted before adding $1 \mathrm{ml}$ of sterile distilled water followed by vortexing. The suspension was transferred into sterile McCartney bottles containing $9 \mathrm{ml}$ of sterile distilled water and mixed by vortexing. Subsequently, the suspension was standardized to optical density of 0.1 at $600 \mathrm{~nm}$. 
The method described by Maki et al. [14] was used to screen the bacterial isolates for cellulase activity. Isolates were grown with shaking in $10 \mathrm{ml}$ of LB broth at $28^{\circ} \mathrm{C}$ for $24 \mathrm{~h}$, and slower-growing isolates were left to incubate for an additional $48 \mathrm{~h}$. All resulting broth cultures were tested for cellulase (endoglucanase) activity using the Gram iodine method [12]. Briefly, the broth culture was standardized as described earlier, $5 \mu \mathrm{l}$ of each culture suspension was placed onto a Petri dish containing carboxymethyl cellulose (CMC) agar, incubated at $28^{\circ} \mathrm{C}$ for $48 \mathrm{~h}$, and flooded with Gram's iodine solution $(2.0 \mathrm{~g}$

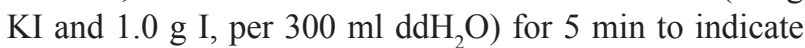
endoglucanase activity. The presence of a halo zone at the point of inoculation with broth culture outwards was indicative of substrate (CMC) degradation by the enzyme present in the fermented broth and hence regarded as a positive reaction. Halo zone diameters were measured for a semi-qualitative comparison of endoglucanase activity among the isolates after $72-96 \mathrm{~h}$ of incubation. The evaluation of xylanase activity in the bacterial isolates followed the same method described for endoglucanase activity (above), except that CMC was replaced with birchwood xylan as substrate.

The bacterial isolate was identified by $16 \mathrm{~S}$ rDNA sequencing. The genomic DNA used for PCR was prepared from the single colonies grown on basal medium for $72 \mathrm{~h}$. The total genomic DNA was extracted with the aid of a DNA purification kit according to the manufacturer's protocol. The $16 \mathrm{~S}$ rDNA gene fragment was amplified using universal primers (16S forward Primer -5'-GCCTAACACATGCAAGTCGA-3' and 16S reverse primer -3'CGTATTACCGCGGCTGCTGG-5') [15]. The following PCR conditions were utilized: initial denaturation at $94^{\circ} \mathrm{C}$ for $3 \mathrm{~min}$ followed by 30 cycles of amplification (Denaturation at $94^{\circ} \mathrm{C}$ for $60 \mathrm{sec}$, annealing temperature is $55^{\circ} \mathrm{C}$ for $60 \mathrm{sec}$, and extension at $72^{\circ} \mathrm{C}$ for $60 \mathrm{sec}$ ) and an addition of $5 \mathrm{~min}$ at $72^{\circ} \mathrm{C}$ as final extension. The amplification reactions were carried out with a total volume of $50 \mu \mathrm{l}$ in a gradient PCR. The PCR products were then visualized using $1 \%$ agarose gel and purified using a PCR clean-up kit according to the manufacturer's instructions. Direct sequencing was performed by dideoxy chain end strategy using a 3100-Avant Genetic Analyzer at Inqaba Biotec. Finally, the obtained sequences were analyzed for homology using BLAST (Entrez Nucleotide database) [16].

A modified method of Poorna and Prema [17] was used for endoglucanase and xylanase production in a submerged fermentation process. The fermentation medium was prepared using $1 \% \mathrm{w} / \mathrm{v}$ carboxymethyl cellulose (as cellulose substrate) and 1\% w/v birchwood xylan (as xylanase substrate), $\mathrm{K}_{2} \mathrm{HPO}_{4} 0.1 \%(\mathrm{w} / \mathrm{v}), \mathrm{MgSO}_{4} .7 \mathrm{H}_{2} \mathrm{O}$ $0.05 \%(\mathrm{w} / \mathrm{v})$, yeast extract $0.05 \%(\mathrm{w} / \mathrm{v}), \mathrm{KCl} 0.1 \%(\mathrm{w} / \mathrm{v})$, and $\mathrm{NaNO}_{3} 0.1 \%(\mathrm{w} / \mathrm{v})$, and was autoclaved at $121^{\circ} \mathrm{C}$ for $15 \mathrm{~min}$. After sterilization, the medium was then allowed to cool to room temperature and then inoculated with $1 \mathrm{ml}$ of the bacterial culture and incubated with shaking $(160 \mathrm{rpm})$ at $28^{\circ} \mathrm{C}$ for $24 \mathrm{~h}$. Subsequently, the fermented broth was centrifuged at $10,000 \mathrm{rpm}, 4^{\circ} \mathrm{C}$ for $5 \mathrm{~min}$, and the cell-free supernatant was used as a crude enzyme source for determining enzyme activity.

Endoglucanase activity was determined according to the method of Jecu [18] using carboxymethyl cellulose $1 \%(w / v)$. The amount of reducing sugars released was determined using dinitrosalicylic acid (DNS) assay [19]. The activity was expressed in international units (IU), defined as the amount of enzyme required to produce $1 \mathrm{mmol}$ glucose per min. The same method was used for xylanase activity, which was determined by measuring the release of reducing sugars from birchwood xylan (in Tris buffer, $50 \mathrm{mM}, \mathrm{pH} 8$ ). One unit of xylanase activity (IU) was defined as the amount of enzyme necessary to release $1 \mathrm{mmol}$ of xylose equivalent per min under assay conditions. All the experiments were carried out independently in triplicate and the results presented here are the means of each set.

The effect of temperature on enzyme production was determined by incubating the production media with shaking at temperatures ranging from $20-50^{\circ} \mathrm{C}$ for $72 \mathrm{~h}$. The culture filtrates were then collected and assayed for endoglucanase or xylanase activities [12].

The effect of $\mathrm{pH}$ on enzyme production was determined by adjusting the initial $\mathrm{pH}$ of the production media to $\mathrm{pH} 6,7,8,9,10$, and 11 using $1 \mathrm{M} \mathrm{HCl}$ or $\mathrm{NaOH}$ prior to autoclaving. The media were incubated at $30^{\circ} \mathrm{C}$ under shaking conditions (160 rpm) for $72 \mathrm{~h}$ and assayed for enzyme activity [21].

To assess the effect of agitation speed on enzyme production, the agitation speed of the production media was varied from $0-300 \mathrm{rpm}$ at $50 \mathrm{rpm}$ incremental levels as described by Adhyaru et al. [22].

In order to achieve maximum endoglucanase or xylanase production, incubation time was varied from 0-108 $\mathrm{h}$. The crude enzyme was extracted and assayed at regular intervals of $12 \mathrm{~h}$. The supernatant was used as the crude enzyme to determine enzyme activity as described by Agnihotri et al. [23].

The experimental data was expressed as mean \pm standard deviation (SD) of the triplicates. Statistical analysis was done using Statistical Package for the Social Sciences (SPSS). The Friedman test was used to compare the data among the parameters that were studied in the research. $\mathrm{p}<0.05$ (Asymp. significance) was considered statistically significant.

\section{Results and Discussion}

Based on the morphological characteristics on R2A agar plates, the bacteria were selected, purified, and stored at $4^{\circ} \mathrm{C}$ for further studies. A total of 52 distinct bacterial colonies were recovered from the sawdust samples, and 11 distinct isolates were screened for endoglucanase and xylanase activities. Eight screened isolates were positive for at least one of the enzymes tested while three were negative for both enzyme activities (Table 1). Three isolates (TC3, PO2, and PYO2) were positive for both endoglucanase and xylanase activities. A total of six isolates 
Table 1. Enzyme activities of selected isolates based on their ability to degrade cellulose and xylan.

\begin{tabular}{|c|c|c|}
\hline Isolate code & $\begin{array}{c}\text { Halo zone } \\
\text { diameter on CMC } \\
\text { (average } \pm \text { SD) }\end{array}$ & $\begin{array}{c}\text { Halo zone } \\
\text { diameter on xylan } \\
\text { (average } \pm \text { SD) }\end{array}$ \\
\hline TC3 & $38.3 \pm 1.15$ & $11.0 \pm 1.41$ \\
\hline BC2 & - & $37.2 \pm 5.13$ \\
\hline PO1 & $51.7 \pm 6.43$ & - \\
\hline PO2 & $37.0 \pm 3.0$ & $55.3 \pm 5.13$ \\
\hline MC0 & $23.3 \pm 5.51$ & - \\
\hline TC1 & - & $9.5 \pm 0.71$ \\
\hline BW0 & - & - \\
\hline PYO1 & $22.0 \pm 7.78$ & - \\
\hline PYO2 & $\mathbf{5 1 . 0 \pm 4 . 3 6}$ & $\mathbf{4 4 . 5} \pm \mathbf{9 . 1 9}$ \\
\hline MW1 & - & - \\
\hline PC1 & - & - \\
\hline
\end{tabular}

(TC3, PO1, PO2, MCO, PYO2, and PYO1) were positive for endoglucanase activity while a total of five (TC3, BC2, $\mathrm{PO} 2, \mathrm{TC} 1$, and PYO2) were positive for xylanase activity (Table 1). Isolate PYO2 exhibited the second-highest endoglucanase activity (51.0 $\mathrm{mm}$ halo zone diameter) and xylanase activity (44.5 $\mathrm{mm}$ halo zone diameter) (Table 1$)$. Because the appearances of the halo zones for both endoglucanase and xylanase activities for PO2 on the basis of the high activity exhibited by PYO2, the isolate was selected for detailed study.

Degradation of cellulosic materials is a complex process and requires participation of microbial cellulolytic enzymes. Habitats where cellulosic materials are present are the best sources for isolating cellulolytic microorganisms [24]. Several microorganisms have been discovered over the past decades which have capacity to convert cellulose into simple sugars [25]; but the need for a newly isolated cellulose-degrading microorganism still continues [26].

Stability is the most critical factor when considering the suitability of enzymes for applications in industrial processes; hence, greater emphasis is placed on the effect of various parameters such as temperature, $\mathrm{pH}$, and inhibiting irons on enzyme stability [27]. There has been great emphasis on the use of fungi because of their ability to produce large amounts of cellulases and hemicellulases, which are secreted into the medium for easy extraction and purification [28]. Nonetheless, a major obstacle for industrial application is that most cellulases of fungal origin lack thermal stability at high temperature [29]. Since most industrial processes are carried out at high temperature, the industrial applications of fungal origin cellulases are correspondingly limited [30]. Bacteria have high growth rate and enzyme production rate as compared to fungi and have good potential to be used in cellulase production [31]. The biotechnological industries have de- veloped an alternative way of improving enzymes production by microorganisms through genetic engineering [32]. In addition, submerged fermentation has mainly been exploited for enzymes production purposes in the biotechnological sector [33].

The Basic Local Alignment Search Tool (BLAST) analyses of the 16S rDNA nucleotide sequences of PYO2 showed it to have $98 \%$ similarity to a Chryseobacterium taichungense strain, and the sequences were deposited in GenBank as Chryseobacterium taichungense SAMRCUFH2 with accession number KU171370. From literature search, Chryseobacterium species are well known for the production of proteolytic enzymes. Nevertheless, there is scant literature on their ability to produce ligninolytic enzymes such as cellulase (endoglucanase), xylanase, ligninase, mannanase, laccase, and others. To the best of our knowledge, this is the first study on the production of endoglucanase and xylanase by Chryseobacterium species. In this present study, the test bacterial strain was isolated from decaying sawdust samples from a wood factory at Melani village in the Eastern Cape Province of South Africa.

The effect of incubation temperature $\left(25-50^{\circ} \mathrm{C}\right)$ on endoglucanase and xylanase production was investigated and the results are presented in Fig. 1. The highest activities for both endoglucanase $(90 \mathrm{U} / \mathrm{ml})$ and xylanase $(420 \mathrm{U} / \mathrm{ml})$ were recorded at $25^{\circ} \mathrm{C}$ (Figs 1-2).

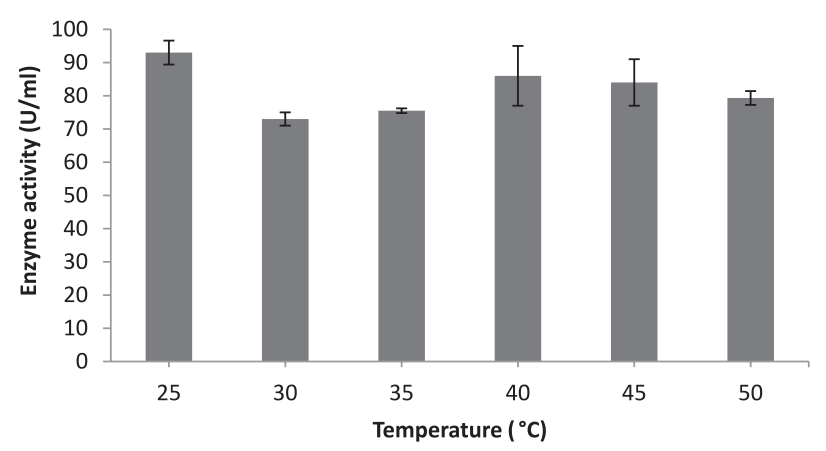

Fig. 1. Effect of incubation temperature on cellulase produced by Chryseobacterium sp. The values are means of the enzyme activities \pm SD of the triplicates ( $p>0.05$ ).

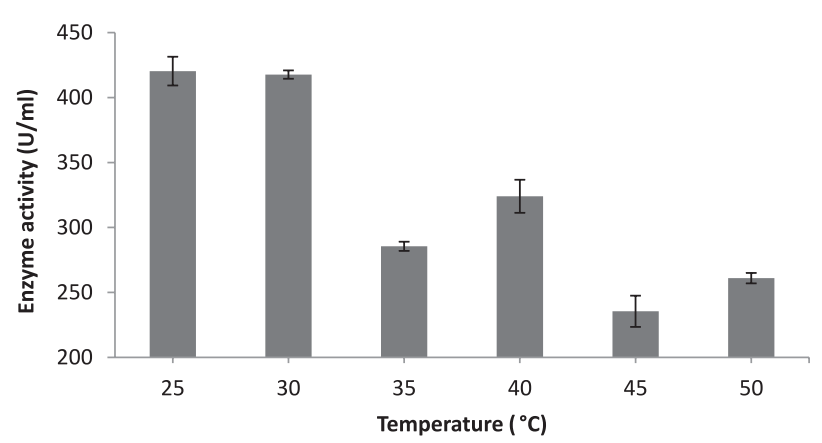

Fig. 2. Effect of incubation temperature on xylanase produced by Chryseobacterium sp. The values are means of the enzyme activities $\pm \mathrm{SD}$ of the triplicates. 
Xylanase activity decreased slightly at $30^{\circ} \mathrm{C}$, followed by a drastic decline at $35^{\circ} \mathrm{C}$ and a slight recovery at $40^{\circ} \mathrm{C}$ with the lowest activity of $235.5 \mathrm{U} / \mathrm{ml}$ recorded at $45^{\circ} \mathrm{C}$ (Fig. 2). A non-parametric Friedman test of differences between endoglucanase and xylanase was conducted and showed an asymptotic significance of 0.306 , which was not significant $(\mathrm{p}>0.05)$. The bacteria displayed high activity of endoglucanase and xylanase under favourable growth conditions. The test bacteria produced both endoglucanase and xylanase optimally at $25^{\circ} \mathrm{C}$ (Figs 1-2). Sharma and colleagues [34] reported two bacterial isolates - B. megaterium $\mathrm{R}_{5}$ and B. subtilis $\mathrm{N}_{11}$ - which displayed minimum xylanase activity at $25^{\circ} \mathrm{C}$, contrary to the results obtained in our study. In another study conducted by Bakare et al. [35], they found that the cellulase produced by Pseudomonas fluorescence was activated from 30 to $35^{\circ} \mathrm{C}$, showing the optimum temperature at $35^{\circ} \mathrm{C}$, whereas Odeniyi et al. [36] documented $37^{\circ} \mathrm{C}$ as a favourable temperature for cellulase production by $\mathrm{Ba}$ cillus coagulans. A Streptomyces ruber was found to show good cellulase production between $35-45^{\circ} \mathrm{C}$ with maximum activity at $40^{\circ} \mathrm{C}$ [37]. According to the report of Immanuel et al. [38], maximum endoglucanase activity from Cellulomonas, Bacillus, and Micrococcus sp. was recorded at $40^{\circ} \mathrm{C}$ and neutral $\mathrm{pH}$. Geobacillus sp. $\mathrm{T} 1$ could not grow at temperatures less than $40^{\circ} \mathrm{C}$; but at temperatures ranging from 40 to $60^{\circ} \mathrm{C}$ this bacterium grew well and produced high amounts of CMCase activity [39]. Among the tested temperatures, the optimum temperature for cellulase production by Geobacillus sp. T1 was $50^{\circ} \mathrm{C}$. Similarly, Abdel-Fattah et al. [40] using optimization methods achieved maximum cellulase activity at $55^{\circ} \mathrm{C}$ for a thermophilic Geobacillus strain isolated from soil.

Murugan et al. [41] and Kumar et al. [42] documented that xylanase produced by Arthrobacter sp. MTCC 6915 and Bacillus pumilus VLK-1 was found to be optimum at $30^{\circ} \mathrm{C}$. However, an increase in temperature beyond $30^{\circ} \mathrm{C}$ led to a decline in the production of the enzyme. The optimum temperature for enzyme production by an organism may vary since it is likely to affect growth of the organism. Irfan et al. [43] reported that the three bacterial strains used in the study did not grow well at $25^{\circ} \mathrm{C}$ and thus resulted in decreased enzyme production. B. subtilis BS04 showed highest enzyme production at $35^{\circ} \mathrm{C}$. Higher incubation temperature also is $50-60^{\circ} \mathrm{C}$, which has been reported by other researchers in the literature [44-49].

The impact of initial $\mathrm{pH}$ of growth medium on endoglucanase and xylanase production was assessed (Figs 3-4). The bacteria could produce endoglucanase at a wide $\mathrm{pH}$ range from 3-11; however, significantly high production was achieved at acidic conditions ( $\mathrm{pH} 3-5)$, with the maximum activity of $101.3 \mathrm{U} / \mathrm{ml}$ at $\mathrm{pH}$ 6. From $\mathrm{pH} 7$, the activity started to drop and slightly picked up at $\mathrm{pH} 8$ and dropped again as $\mathrm{pH}$ increased with the lowest $\mathrm{pH}$ of $65 \mathrm{U} / \mathrm{ml}$ being observed at $\mathrm{pH} 11$ (Fig. 3). As illustrated in Fig. 4, xylanase activity was investigated as well and the results showed that the highest xylanase activity of $384.3 \mathrm{U} / \mathrm{ml}$ was recorded at weak acidic $\mathrm{pH}$ of 6 , which was similar to the $\mathrm{pH}$ for optimal

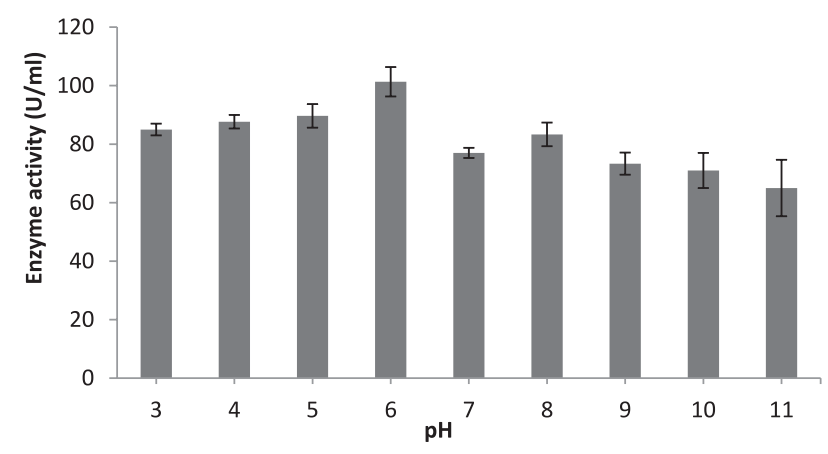

Fig. 3. Effect of initial culture medium $\mathrm{pH}$ on cellulase produced by Chryseobacterium sp. The values are means of the enzyme activities $\pm \mathrm{SD}$ of the triplicates.

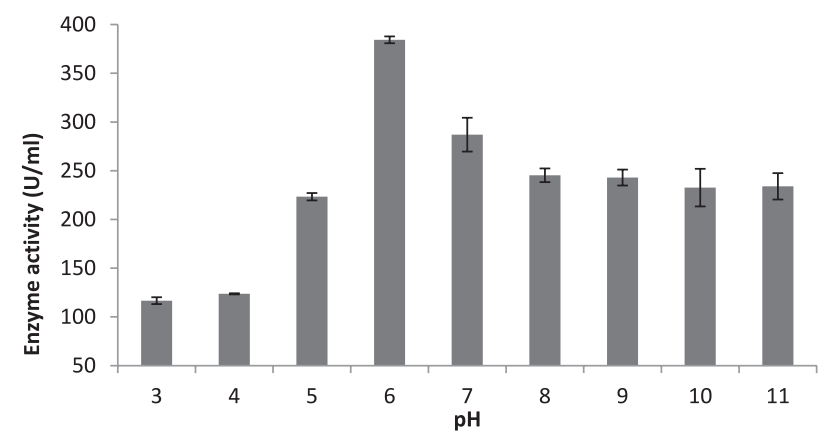

Fig. 4. Effect of initial culture medium $\mathrm{pH}$ on xylanase produced Chryseobacterium sp. The values are means of the enzyme activities \pm SD of the triplicates.

endoglucanase production previously reported. After $\mathrm{pH}$ 6 , a steady decrease in xylanase production was observed (Fig. 4). The alkaline conditions (8-11) supported higher xylanase production compared to acidic conditions (3-5).

A non-parametric Friedman test of differences between endoglucanase and xylanase activities was conducted and had an asymptotic significance of 0.460 , which was not significant $(\mathrm{p}>0.05)$. Enzyme production by microorganism can be influenced by the $\mathrm{pH}$ of the medium in two ways; firstly, it can affect the growth of the microorganism, which in turn affects enzyme production; secondly, the unfavourable ionic environment which is caused by initial $\mathrm{pH}$ of the medium may lead to denaturation or inactivation of the produced enzyme [50-51]. The initial $\mathrm{pH}$ also affects the transportation of different enzymes across the cell membrane [52]. In our present study, the bacteria displayed the highest activity for enzyme production at $\mathrm{pH} 6$ for both endoglucanase and xylanase (Figs 3-4). This indicates that slightly acidic conditions favoured both bacterial growth and enzyme production.

Xylanase production by various bacteria has been shown to be predominantly dependent on the $\mathrm{pH}$ of the medium. Acidic $\mathrm{pH}(4.0-6.0)$ generally favours endoglucanases while higher $\mathrm{pH}$ usually favours xylanases [27]. Bacillus licheniformis $\mathrm{K}_{22}$ has been reported to significantly exhibit high cellulase production 
at pH 6.5 [34], an observation that is in agreement with the results reported in this study. Jaradat et al. [53] found that Streptomyces sp. (strain J2) displayed cellulase activity at a $\mathrm{pH}$ range of 4-7 with maximum activity at $\mathrm{pH} 6$. In the case of an Ire and Berebon [54] report, maximum endoglucanase pro-duction by $P$. aeruginosa was observed at $\mathrm{pH} 5.5$ and least enzyme production was observed at $\mathrm{pH}$ 3 when corncob was used as a carbon source. According to a general observation of the effect of $\mathrm{pH}$ on enzyme production, optimum $\mathrm{pH}$ is required to maintain the threedimensional shape of the active site of enzyme, and the change in $\mathrm{pH}$ results in loss of functional shape of enzyme due to alterations in the ionic bonding of the enzyme [55]. In addition, each microorganism requires an optimum $\mathrm{pH}$ for its growth and activity. Thus, the optimum $\mathrm{pH}$ for enzyme production varies from one bacterial strain to another [42]. The initial $\mathrm{pH}$ of the medium may influence many enzymatic systems and the transport of enzymes across the cell membrane.

Remarkably, Geobacillus sp. T1 was able to grow and produce cellulase over a wide range of $\mathrm{pH}$ (4.5-9.5). The highest enzyme production by Geobacillus sp. T1 was obtained at pH 6.5 [39]. Similarly, this observation is in collaboration with the report of Rastogi et al. [56], who found $\mathrm{pH} 7$ for maximum cellulase production by another thermophilic Geobacillus strain with most similarity with Geobacillus thermoleovorans. In the case of the report of Han et al. [57], Sepahy et al. [45], and Bajaj and Manhas [58], and xylanase production by Bacillus NT 9, Bacillus mojavensis AG137, and B. licheniformis P11(C) it was observed over a wide $\mathrm{pH}$ range in acidic, neutral, and alkaline conditions with maximum production at medium between $\mathrm{pH} 8$-10. Thus, these organisms have not only grown successfully at acidic and alkaline $\mathrm{pH}$, but also generated considerable enzyme titre.

Most of the bacteria are dependent on $\mathrm{pH}$ and produce xylanase under high $\mathrm{pH}[17,32]$. For the production of cellulase by Bacillus subtilis and Bacillus circulans, $\mathrm{pH}$ in the range of 7.0-7.5 was found to be optimum by Ray et al. [59]. According to the report of Irfan et al. [43], pH 8 was the best among the $\mathrm{pH}$ values of the medium for xylanase production by $B$. subtilis BS04 and B. megaterium BM07 in submerged fermentation. In addition, lower $\mathrm{pH}$, i.e., 4 and higher $\mathrm{pH}$, i.e., 10 of the medium retards xylanase secretion drastically. These results indicated that both bacterial strains can tolerate alkaline conditions.

The effect of agitation speed on both endoglucanase and xylanase production was conducted using a shaking speed range of 0-200 rpm with $50 \mathrm{rpm}$ incremental levels. The highest endoglucanase activity was observed at $50 \mathrm{rpm}$. Endoglucanase production was observed at agitation speed of 100-200 rpm and subsequently dropped slightly in a fluctuating pattern. The lowest endoglucanase activity of $75.5 \mathrm{U} / \mathrm{ml}$ was observed at $0 \mathrm{rpm}$ (Fig. 5). With respect to xylanase, activity increased steadily from the static conditions with the lowest xylanase activity of $118 \mathrm{U} / \mathrm{ml}$, peaking at $150 \mathrm{rpm}$ with $270.5 \mathrm{U} / \mathrm{ml}$ recorded and then followed by a noticeable decline at 200 rpm (Fig. 6). A non-parametric Friedman test of dif-

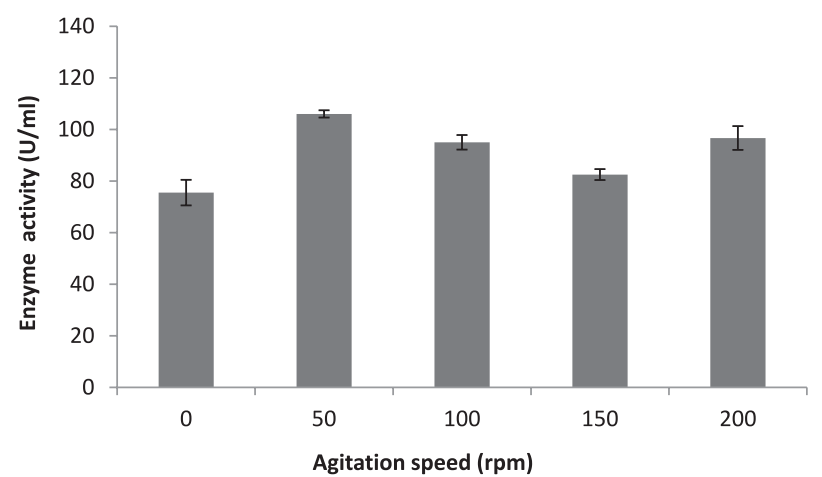

Fig. 5. Effect of agitation speed on cellulase produced by Chryseobacterium sp. The values are means of the enzyme activities \pm SD of the triplicates.

ferences among enzyme activities for endoglucanase and xylanase was conducted and had an asymptotic significance of 0.406 , which was significant $(p<0.05)$. The results obtained from this present study showed that the bacteria produced endoglucanase optimally at agitation speed of $50 \mathrm{rpm}$, above which a fluctuating decrease in enzyme activity was observed (Fig. 5). The reduction in enzyme activity with increasing agitation speed may be due to shearing of the cells [20]. The report of EI-Refai et al. [60] concurs with our findings, in which the best agitation rate for cellulase was found to be between 0 and $50 \mathrm{rpm}$. For xylanase, production was optimal at agitation speed of $150 \mathrm{rpm}$.

The reason for low enzyme activity at low agitation speed may also be attributed to the limitation of the dissolved oxygen and to the inadequate mixing of the medium components due to the low speed used. However, the strain displayed a very good pattern for the production of xylanase (Fig. 6). The highest xylanase production by $B$. pumilus VLK-1 was observed at an agitation rate of $200 \mathrm{rpm}$ after $48 \mathrm{~h}$ of incubation [42]. The enzyme yield was low when the agitation rate was increased or decreased beyond $200 \mathrm{rpm}$. This was consistent with

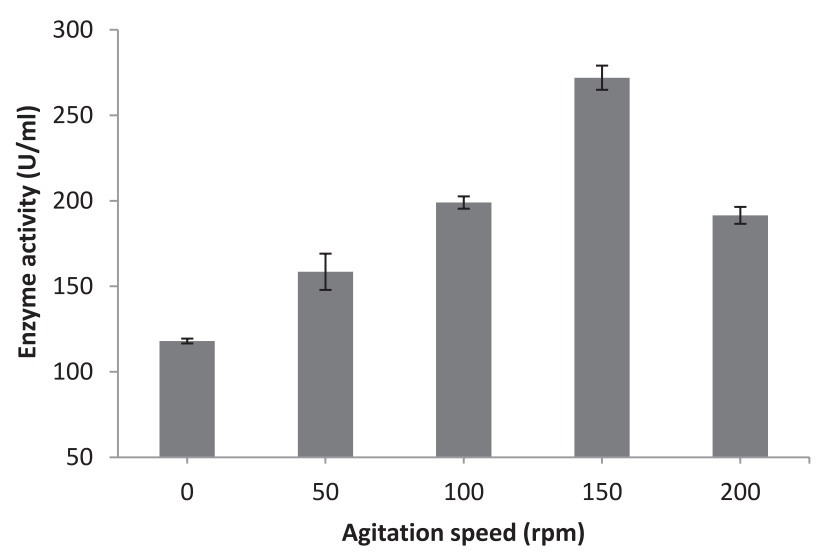

Fig. 6. Effect of agitation speed on xylanase produced by Chryseobacterium sp. The values are means of the enzyme activities \pm SD of the triplicates. 


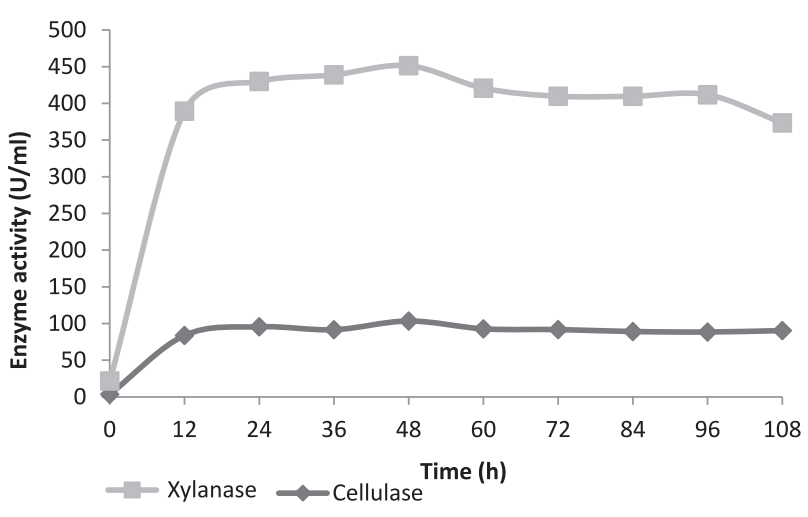

Fig. 7. Time course of cellulase and xylanase produced by Chryseobacterium sp. The values are means of the enzyme activities \pm SD of the triplicates.

earlier reports $[45,61]$. The lower enzyme level under low agitation conditions may be attributed to the dissolved oxygen limitation for cell growth, improper mixing of media components, and cell clumping.

Time course experimentation was conducted using the optimum culture conditions obtained for the endoglucanase and xylanase production and the results obtained are illustrated in Fig. 7. The bacteria showed a steady increase in endoglucanase production and attained a peak in $48 \mathrm{~h}$ with enzyme activity of $103.3 \mathrm{U} / \mathrm{ml}$. Subsequently, endoglucanase production declined to about $92 \mathrm{U} / \mathrm{ml}$ and remained relatively constant at this level for the rest of the fermentation period. Moreover, xylanase production increased steadily, attaining a peak in $48 \mathrm{~h}$ with an activity of $348 \mathrm{U} / \mathrm{ml}$ and thereafter declined to $283 \mathrm{U} / \mathrm{ml}$ at $108 \mathrm{~h}$ (Fig. 7). A non-parametric Friedman test of differences among enzyme activities for endoglucanase and xylanase was conducted and had an asymptotic significance of 0.071 , which was considered as weakly significant ( $p$ slightly $>0.05$ ). In order to obtain efficient enzyme production, it is critical to consider optimum cultivation conditions for a specific microorganism. For time course assay, the optimum culture conditions discussed above were used for the experiment. Time course experimentation was used to determine the incubation time at which the enzymes will be maximally produced under optimized culture conditions in order to know what may be the bacterial strain can produce the enzyme of interest within a shorter period of time. The advantage of a shorter incubation period for enzyme production is that the bulk production of the enzymes may be achieved over a short period of time, which implies cost-containing possibilities on an industrial production scale. Fermentation time for maximum enzyme production varies among different bacteria and is dependent upon the type of the organism, culture/environmental conditions, and genetic makeup of the organism.

In this present study, Chryseobacterium sp. was observed to display highest enzyme production for both endoglucanase and xylanase after $48 \mathrm{~h}$ of cultivation period and, subsequently, enzyme production started to decrease uniformly, resulting in almost a constant pattern for endoglucanase, and the lowest enzyme activity was observed after $108 \mathrm{~h}$ for xylanase (Fig. 7). It has been suggested that the depletion of nutrients in the fermentation medium causes the reduction in enzyme production and this usually occurs after the log phase or at the beginning of the death phase of the incubation period [20]. On the contrary, the study on B. pumilus EB3 by Ariffin et al. [62] showed lesser CMCase activity (0.079 IU/ $\mathrm{ml}$ ) after $24 \mathrm{~h}$ of incubation. Nagendra et al. [63] noticed that the optimum incubation period for cellulase was also within $96 \mathrm{~h}$ in late stationary phase of growth. Lugani et al. [55] reported that maximum cellulase production by Bacillus sp. was observed at $96 \mathrm{~h}$ of incubation, and that the activity was significantly reduced after $96 \mathrm{~h}$ due to depletion of nutrients or accumulation of other by-products in the fermentation media, which lead to a decrease in cellulase activity [64]. The maximum cellulase production by thermophilic Bacillus sp. was observed after $96 \mathrm{~h}$ of incubation [24]. In collaboration with our findings in this present study for xylanase, optimal production after $48 \mathrm{~h}$ of incubation, several researchers have documented this cultivation time for their xylanase production. For example, Bacillus sp. NZ produced maximum enzyme titre near the end of the exponential phase and early stationary phase [65]. B. cereus [66] and B. halodurans PPKS-2 [67] showed maximum xylanase production after $48 \mathrm{~h}$. Gupta and Kar [68] studied xylanase production by Bacillus sp. and reported that maximum xylanase production was observed in $48 \mathrm{~h}$ and $72 \mathrm{~h}$ using wheat bran and corn cob as a substrate, respectively. Mrudula and Shyam [69] reported $48 \mathrm{~h}$ of fermentation time for maximum production of protease from B. megaterium MTTC 2444. Sepahy et al. [45] reported a fermentation period of $48 \mathrm{~h}$ by Bacillus mojavensis AG137 in submerged fermentation using oat bran as a substrate. On the other hand, contrary to our findings, a shorter cultivation period was recorded for maximum xylanase production by Bacillus sp. after 24 $\mathrm{h}$ using digested bran as a substrate [46].

\section{Conclusions}

The optimization of media is an important parameter for the development of fermentation technology because a cost-effective media results in the reduction of cost of enzyme. Hence, the optimization of all the process parameters are being considered as pre-requisites to make the process of enzyme production cost-effective on a large scale. Findings from this study indicated that nutrients and cultural properties played a pivotal role in enzyme production. Chryseobacterium species isolated from decaying sawdust samples collected from a wood factory in a village in South Africa's Eastern Cape Province displayed similar optimum growth conditions for both endoglucanase and xylanase production for almost all the parameters that were investigated in this present study, with the exception of agitation speed. A similar pattern for time course assay for both cellulase and xylanase 
production was observed. This study confirms the potential of the test bacteria in lignocellulosic materials degradation and that the detailed characterization of the purified enzymes and development of process conditions for their pilot scale production is an on-going study in our research group. In addition, the molecular biology on the genetic basis of enzyme production and how their yields can be improved through genetic engineering is currently under investigation in our laboratory.

\section{Acknowledgements}

We are grateful to the National Research Foundation (NRF) of South Africa, the Medical Research Council of South Africa, and University of Fort Hare for their financial support

\section{References}

1. ABO-STATE M.A.M., GHALY M.F. ABDELLAH E.M. Production of cellulases and xylanase by thermophilic and alkaliphilic bacterial strains isolated from agricultural wastes. World Appl Sci J. 22, 1603, 2013.

2. CHAPLA D., DIVECHA J., MADAMWAR D., SHAH A. Utilization of agro-industrial waste for xylanase production by Aspergillus foetidus MTCC 4898 under solid state fermentation and its application in saccharification. Biochem Eng J. 49, 361, 2010.

3. KOO Y.M. Pilot-scale production of cellulase using Trichoderma reesei Rut C-30 in fed-batch mode. J Microbiol Biotechnol. 11, 229, 2001.

4. LEE Y.J., KIM B.K. LEE B.H. JO K.I., LEE N.K., CHUNG C.H., LEE Y.C., LEE J.W. Purification and characterization of cellulase produced by Bacillus amyoliquefaciens DL-3 utilizing rice hull. Biores Technol. 99, 378, 2008.

5. BEG Q., KAPOOR M., MAHAJAN L., HOONDAL G.S. Microbial xylanases and their industrial applications: a review. Appl Microbiol Biotechnol. 326, 56, 2001

6. POLIZELI M.L.T.M., RIZZATTI A.C.S., MONTI R., TERENZI H.F., JORGE J.A., AMORIM D.S. Xylanases from fungi: properties and industrial applications. Appl Microbiol Biotechnol. 67, 577, 2005.

7. MOTTA F.L., ANDRADE C.C.P., SANTANA M.H.A. A review of xylanase production by the fermentation of xylan: classification, characterization and applications. Sustainable Degradation of Lignocellulosic Biomass-Techniques, Applications and Commercialization. 2013.

8. ZHANG Y.H.P., HIMMEL M.E., MIELENZ J.R. Outlook for cellulase improvement: screening and selection strategies. Biotechnol Adv. 24, 452, 2006.

9. BERNARDET J.F., NAKAGAWA Y. An introduction to the family Flavobacteriaceae. In The prokaryotes 455. Springer New York. 2006.

10. BEKKER A. Growth and Spoilage Characteristics of (Doctoral dissertation, University of the Free State). 2011.

11. BERNARDET J.F., VANCANNEYT M., MATTETAILLIEZ O., GRISEZ L., TAILLIEZ P., BIZET C., NOWAKOWSKI M., KEROUAULT B., SWINGS J. Polyphasic study of Chryseobacterium strains isolated from diseased aquatic animals. Systematic and Appl Microbial. 640, 28, 2005.
12. KASANA R.C., SALWAN R., DHAR H., DUTT S., GULATI A. A rapid and easy method for the detection of microbial cellulases on agar plates using Gram's iodine. Curr Microbiol. 57, 503, 2008.

13. JEFFREY L.S.H. Isolation, characterization and identification of actinomycetes from agriculture soils at Semongok, Sarawak. Afr J Biotechnol. 7, 3697, 2000.

14. MAKI M.L., BROERE M., LEUNG K.T., QIN W. Characterization of some efficient cellulase producing bacteria isolated from paper mill sludges and organic fertilizers. Int J Biochem Mol Biol. 2, 146, 2011.

15. SACCHI C.T., WHITNEY A.M., MAYER L.W., MOREY R., STEIGERWALT A., BORAS A., WEYANT R.S., POPOVIC T. Sequencing of 16S rRNA gene: a rapid tool for identification of Bacillus anthracis. Emerging infectious diseases 8, 1117, 2002.

16. MANGAMURI U.K., MUVVA V., PODA S., KAMMA S. Isolation, identification and molecular characterization of rare actinomycetes from mangrove ecosystem of Nizampatnam. Mal J Microbiol. 8, 83, 2012.

17. POORNA C.A., PREMA P. Production and partial characterization of endoxylanase by Bacillus pumilus using agro industrial residues. Biochem Eng J. 32, 106, 2006.

18. JECU L., Solid state fermentation of agricultural wastes for endoglucanase production. Indust Crops and Prod. 11, 1, 2000.

19. MILLER G.L. Use of dinitrosalicylic acid reagent for determination of reducing sugar. Analyt Chem. 31, 426, 1959.

20. KUMAR A., GUPTA R., SHRIVASTAVA B., KHASA Y.P., KUHAD R.C. Xylanase production from an alkalophilic actinomycete isolate Streptomyces sp. RCK-2010, its characterization and application in saccharification of second generation biomass. J Mol Cat B: Enz. 74, 170, 2012.

21. BAJAJ B.K., KHAJURIA Y.P., SINGH V.P. Agricultural residues as potential substrates for production of xylanase from alkali-thermotolerant bacterial isolate. Biocat Agric Biotechnol. 314, 1, 2012

22. ADHYARU D.N., BHATT N.S., MODI, H.A. Enhanced production of cellulase-free, thermo-alkali-solvent-stable xylanase from Bacillus altitudinis DHN8, its characterization and application in sorghum straw saccharification. Biocataly Agric Biotechnol. 182, 3, 2014.

23. AGNIHOTRI S., DUTT D., TYAGI C.H. KUMAR A. UPADHYAYA J.S. Production and biochemical characterization of a novel cellulase-poor alkali-thermotolerant xylanase from Coprinellus disseminatus SW-1 NTCC 1165. World J Microbiol Biotechnol. 1349, 26, 2010.

24. DAS A., BHATTACHARYA S., MURALI L. Production of cellulase from a thermophilic Bacillus sp. isolated from cow dung. American-Eurasian J Agric Environ Sci. 8, 685, 2010.

25. PEREZ J., MUNOZ-DORADO J., DE LA R.T., MARTINEZ J. Biodegradation and biological treatments of cellulose, hemicellulose and lignin: an overview. Int Microbiol. 5, 53, 2002.

26. NIRANJANE A.J., MADHOU P., STEVENSON T.W. The effect of carbohydrate carbon sources on the production of cellulase by Phlebia gigantean. Enz Microbiol Technol. 40, 1464, 2007

27. BATTAN B., SHARMA J., DHIMAN S.S., KUHAD R.C. Enhanced production of cellulase-free thermostable xylanase by Bacillus pumilus ASH and its potential application in paper industry. Enz Microbial Technol. 733, 41, 2007.

28. MAKI M., LEUNG K.T., QIN W. The prospects of cellulaseproducing bacteria for the bioconversion of lignocellulosic biomass. Int J Biol Sci. 5, 500, 2009. 
29. ACHARYA S., CHAUDHARY A. Optimization of fermentation conditions for cellulases production by Bacillus licheniformis MVS1 and Bacillus sp. MVS3 isolated from Indian hot spring. Braz Arch Biol Technol. 55, 497, 2012.

30. ACHARYA S., CHAUDHARY A. Effect of nutritional and environmental factors on cellulases activity by thermophilic bacteria isolated from hot spring. J Sci Ind Res. 70, 142, 2011.

31. LADEIRA S.A., CRUZ E., DELATORRE A.B., BARBOSA J.B., MARTINS M.L.L. Cellulase production by thermophilic Bacillus sp. SMIA-2 and its detergent compatibility. Electron J Biotech. 18, 110, 2015.

32. BAJAJ B.K., SINGH N.P. Production of xylanase from an alkali tolerant Streptomyces sp. $7 \mathrm{~b}$ under solid-state fermentation, its purification, and characterization. Appl Biochem Biotechnol. 1804, 162, 2010.

33. SUBRAMANIYAN S., PREMA P. Biotechnology of microbial xylanases: enzymology, molecular biology, and application. Critical Rev Biotechnol. 22, 33, 2002.

34. SHARMAN., BURAGOHAIN P., TANDON D., KAUSHAL R. Comparative study of potential cellulolytic and xylanolytic bacteria isolated from compost and their optimization for industrial use. J Agroaliment Proc Technol. 19, 284, 2013.

35. BAKARE M.K., ADEWALE I.O., AJAYI A., SHONUKAN O.O. Purification and characterization of cellulose from the wild-type and two improved mutants of Pseudomonas fluorescens. Afr J Biotechnol. 4, 898, 2005.

36. ODENIYI O.A., ONILUDE A.A., AYODELE M.A. Production characteristics and properties of cellulase/ polygalacturonase by a Bacillus coagulans strain from a fermenting palm-fruit industrial residue. Afr J Microbiol Res. 3, 407, 2009.

37. EL-SERSY N.A., ABD-ELNABY H., ABOU-ELELA G.M., IBRAHIM H.A., EL-TOUKHY N.M. Optimization, economization and characterization of cellulase produced by marine Streptomyces ruber. Afr J Biotechnol. 635, 9, 2013.

38. IMMANUEL G., DHANUSHA R., PREMA P., PALAVESAM A. Effect of different growth parameters on endoglucanase enzyme activity by bacteria isolated from coir retting effluents of estuarine environment. Int J Environ Sci Technol. 3, 25, 2006.

39. ASSAREH R., HOSSEIN S.Z., NOGHABI K.A., AMINZADEH S., GHOLAMREZA B.K. Characterization of the newly isolated Geobacillus sp. T1, the efficient cellulase-producer on untreated barley and wheat straws. Biores Technol. 120, 99, 2012.

40. ABDEL-FATTAH Y.R., EL-HELOW E.R., GHANEM K.M., LOTFY W.A. Application of factorial designs for optimization of avicelase production by a thermophilic Geobacillus isolate. Res J Microbiol. 2, 13, 2007.

41. MURUGAN S., ARNOLD D., PONGIYA U.D., NARAYANAN P.M. Production of xylanase from Arthrobacter sp. MTCC 6915 using saw dust as substrate under solid state fermentation. Enz Res. 7. 2011. http:// dx.doi.org/10.4061/2011/696942 (Article ID 696942).

42. KUMAR L., DAVENDER K., SUSHIL N., RISHI G., NEELAM G., RAMESH C.K., VIJAY KUMAR G. Modulation of xylanase production from alkaliphilic Bacillus pumilus VLK-1 through process optimization and temperature shift operation. 3 Biotech 4, 345, 2014.

43. IRFAN M., UMAR A., MUHAMMAD N., RUBINA N., QURATULAIN S. Optimization of process parameters for xylanase production by Bacillus sp. in submerged fermentation. J Rad Res Appl Sci. 9, 139, 2016.

44. MONISHA R., UMA M.V., MURTHY V.K. Partial purification and characterization of Bacillus pumilus xylanase from soil source. Kathmandu University J Sci Eng Tech. 5, 137, 2009.

45. SEPAHY A.A., GHAZI S., SEPAHY M.A. Cost-effective production and optimization of alkaline xylanase by indigenous Bacillus mojavensis AG137 fermented on agricultural waste. Enz Res. 9, 2011. http://dx.doi. org/10.4061/2011/593624 (Article ID 593624).

46. SIMPHIWE P., ADEMOLA B., OLANIRAN O., PILLAY B. Sawdust and digestive bran as cheap alternate substrates for xylanase production. Afr J Microbiol Res. 5, 742, 2011.

47. NAGAR S., GUPTA V.K., KUMAR D., KUMAR L., KUHAD R.C. Production and optimization of cellulasefree, alkali-stable xylanase by Bacillus pumilus SV-85S in submerged fermentation. J Ind Microbiol Biotechnol. 37, 71, 2010.

48. ANNAMALAI N., THAVASI R., JAYALAKSHMI S., BALASUBRAMANIAN T. Thermostable and alkaline tolerant xylanase production by Bacillus subtilis isolated from marine environment. Indian J Biotechnol. 8, 291, 2009.

49. ANAND A., KUMAR V., SATYANARAYANA T. Characteristics of thermostable endoxylanase and b-xylosidase of the extremely thermophilic bacterium Geobacillus thermodenitrificans TSAA1 and its applicability in generating xylooligosaccharides and xylose from agroresidues. Extremophiles 17, 357, 2013.

50. SÁ-PEREIRA P., MESQUITAA., DUARTE J.C., BARROS M.R.A., COSTA-FERREIRA M. Rapid production of thermostable cellulase-free xylanase by a strain of Bacillus subtilis and its properties. Enz Microb Technol. 30, 924, 2002.

51. SHARMA P., BAJAJ B.K. Production and partial characterization of alkali-tolerant xylanase from an alkalophilic Streptomyces sp. CD3. J Sci Indust Res. 64, 688, 2005.

52. KAPOOR M., NAIR L.M., KUHAD R.C. Cost-effective xylanase production from free and immobilized Bacillus pumilus strain MK001 and its application in saccharification of Prosopis juliflora. Biochem Eng J. 38, 88, 2008.

53. JARADAT Z., DAWAGREH A., ABABNEH Q., SAADOUN I. Influence of culture conditions on cellulase production by Streptomyces sp. (strain J2). Jordan J Biol Sci. 1, 141, 2008.

54. IRE F.S., BEREBON D.P. Production and characterization of crude 1, 4- $\beta$-endoglucanase by Pseudomonas aeruginosa using corn (Zea mays) cobs and pawpaw (Carica papaya) fibres as substrates. J Adv Biol Biotechnol. 8, 1, 2016.

55. LUGANI Y., SINGLA R., SOOCH B.S. Optimization of Cellulase Production from Newly Isolated Bacillus sp. Y3. J Bioproc Biotech. 5, 264, 2015. doi:10.4172/21559821.1000264.

56. RASTOGI G., BHALLA A., ADHIKARI A., BISCHOFF K.M., HUGHES S.R., CHRISTOPHER L.P., SANI R.K., Characterization of thermostable cellulases produced by Bacillus and Geobacillus strains. Biores Technol. 101, 8798, 2010.

57. HAN X., ZHENG L., LIAN S., XIE Y. Study on screening and cultivation conditions xylanase producing alkalophilic bacteria. Wuhan Univ J Nat Sci. 9, 125, 2004.

58. BAJAJ B.K., MANHAS K. Production and characterization of xylanase from Bacillus licheniformis P11(C) with potential for fruit juice and bakery industry. Biocat Agric Biotechnol. 1, 330, 2012.

59. RAY A.K., BAIRAGI A., GHOSH K.S., SEN S.K. Optimization of fermentation conditions for cellulase 
production by Bacillus subtilis CY5 and Bacillus circulans TP3 isolated from fish gut. Acta lchthyologica ET Piscatoria. 37, 47, 2007.

60. EL-REFAI H.A., ABDELRAHMAN H.Y., ABDULLA H., HANNA A.G., HASHEM A.H., EL-REFAI AH., AHMED E.M. Studies on the production of actinomycin by Nocardioides luteus, a novel source. Curr Trends in Biotechnol Pharm. 5, 1282, 2011,

61. SANGHI A., GARG N., GUPTA V.K., MITTAL A., KUHAD R.C., One step purification and characterization of a cellulase free xylanase produced by alkalophilic Bacillus subtilis ASH. Braz J Microbiol. 41, 467, 2010.

62. ARIFFIN H., ABDULLAH N., UMI KALSOM M.S., SHIRAI Y., HASSAN M.A. Production and characterisation of cellulase by Bacillus pumilus EB3. Int J Eng Technol. 3, 47, 2006.

63. NAGENDRA H., SOUTHWORTH J., TUCKER C. Accessibility as a determinant of landscape transformation in western Honduras: linking pattern and process. Landscape Ecology 18, 141, 2003.

64. HAQ I.U., HAMEED U., SHAHZADI K., JAVED M., ALI S. Cotton saccharifying activity of cellulases by Trichoderma harzianum UM-11 in shake flask. Int J Bot. 1, 19, 2005.
65. NIZAMUDEEN S., BAJAJ B.K. A novel thermo-alkali tolerant endoglucanase production using cost-effective agricultural residues as substrates by a newly isolated Bacillus sp. NZ. Food Technol. Biotechnol. 47, 435, 2009.

66. FATOKUN E.N., NWODO U.U., OKOH A.I. Classical optimization of cellulase and xylanase production by a marine Streptomyces species. Appl Sci. 6, 286, 2016. doi:10.3390/app6100286.

67. PRAKASH P., JAYALAKSHMI S.K., PRAKASH B., RUBUL M., SREERAMULU K. Production of alkaliphilic, halotolerent, thermostable cellulose free xylanase by Bacillus halodurans PPKS-2 using agro waste: single step purification and characterization. World J Microbiol Biotechnol. 82, 183, 2011.

68. GUPTA U., KAR, R. Xylanase production by a thermotolerant Bacillus species under solid-state and submerged fermentation. Braz Arch Biol Technol. 52, 1363, 2009.

69. MRUDULA S., SHYAM N. Immobilization of Bacillus megaterium MTCC 2444 by Ca-alginate entrapment method for enhanced alkaline protease production. Braz Arch Biol Technol. 55, 135, 2012. 